\title{
Renovation and Representation: Schinkel's Neue Wache and the Politics of German Memory
}

\author{
WALLIS MILLER \\ University of Kentucky \\ USA
}

Since the beginning of the 18 th century, the instability of the Prussian/German state has affected the shape of Berlin. Constant shifts in the boundaries of the empire as well as in its ideology have forced countless architectural redefinitions of the center of its capital. The decisions to preserve, renovate, or replace Berlin's monuments have thus always been caught between considerations of their ideological impact and their effect on the body of historic documentation. Schinkel's Neue Wache grew out of this tension. It was originally designed and subsequently renovated at significant points of change in German history: it was designed after the defeat of Napoleon and renovated after WWI, modified during the Nazi period, and substantially changed at three points after WWII: in the early years of the German Democratic Republic, at the height of the Cold War, and after reunification in 1993. Consequently, its architecture has always borne traces of history consciously transformed by the ideologies of the present.

Given that the building is a memorial, it is no surprise that it is the locus of a confrontation of history and ideology, or, more precisely, a confrontation of history and memory and of the past and the present. The mutual dependency within each of these pairs is revealed by the fact that each member is often defined in terms of the other. In his study of History and Memory, the historian Jacques LeGoff describes memory as "the raw material of history," while "history nourishes

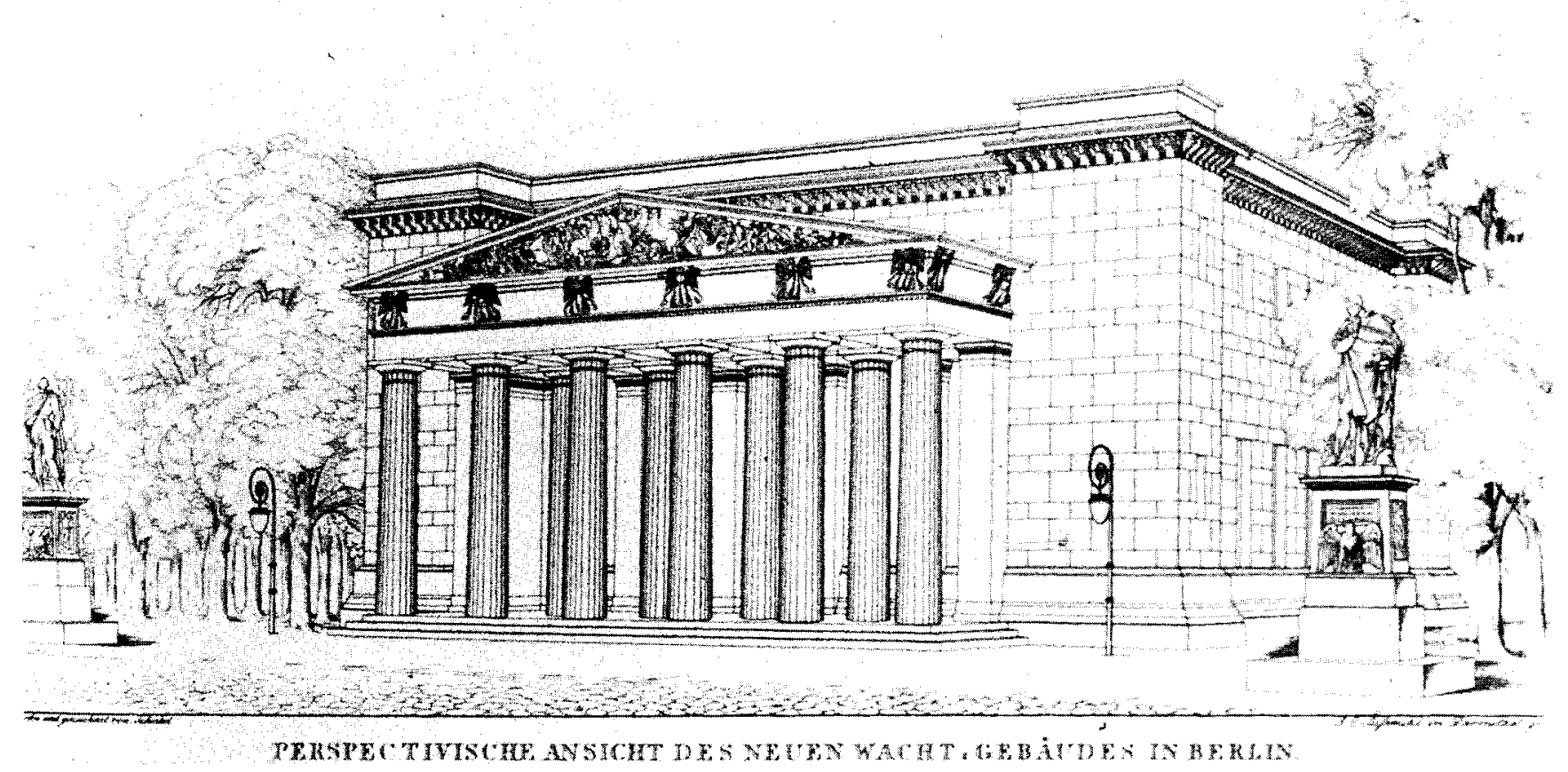

Fig. 1. The Neue Wache viewed from Unter den Linden. From Karl Friedrich Schinkel, Sammlung Architektonischer Entwürfe, translated as Collection of Architectural Drawings. (original: Berlin: Ernst und Korn, 1866) (reprint: New York: Princeton University Press, 1989), Plate 2. 
memory in turn, and enters into the great dialectical process of memory and forgetting experienced by individuals and societies." The two terms fluctuate between identical and independent states, in which history remains closest to the event itself, to the objective, and to a notion of truth, and memory is colored by experience, ideology, by the search for power ${ }^{2}$, and by imagination. According to Vico:

The Latins call memory memoria when it retains sense perceptions, and reminiscentia when it gives them back to us. But they designated in the same way the faculty by which we form images, which the Greeks called phantasia, and which we call imaginativa; for where we vulgarly say imaginare, the Latins said memorare...Thus the Greeks say in their mythology that the Muses, the powers of imagination, are the daughters of Memory. ${ }^{3}$

The intimacy of memory and imagination implies a similar intimacy of past and present. These reciprocities are played out throughout the life of the Neue Wache.

From the time of the first design phase to the present, the Neue Wache has used these complex relationships as the means to portray German identity. As the Royal Guard House, the building stood on Unter den Linden as one in a collection of early monuments to the public; after the dissolution of the German monarchy, the building was repeatedly chosen as the site of the National Memorial. While each memorial mourned human death, it also marked the birth of a new type of government born out of political death. In each case, the present was a product of the past. Consequently, it was most important for those in charge of the project to define the past carefully. The technique of renovation became their means to construct the past as they revealed the complex relationships between past and present and between history and memory before the general public. While the Neue Wache may have been ultimately selected as the site of Germany's National Memorial because of its ties with the origins of the modern German state and because of its location on the major ceremonial axis in the country's capital city, renovation was not merely an artifact of the pragmatic requirements of the project. It was an ideological tool, as integral a part of the substance of German identity as was the content of the memorial itself. This is not only relevant to the twentieth century renovation projects, whose explicit goal was to create a Memorial, but to the original Neue Wache as well, which, I contend, Schinkel likewise created as a renovated building.

The Neue Wache was one of the first signs of German pride after the defeat of Napoleon; King Friedrich Wilhelm III commissioned the project that was built between 1816 and 1818 in order to express the public importance of the Prussian victory over the French as well as to provide himself with a guardhouse for his new residence across the street. Thus, the building formed a major part of the King's plan to transform the center of Berlin from a closed royal enclave, protected by the military, into an area open to the public. The nature of the Neue Wache project placed the military in the pivotal role of the agent who would unite the general public with the monarchy in the center of the city.

The King's correction to Schinkel's 1816 site plan revealed that there was a difference between his interpretation of the situation and that of Schinkel. Schinkel had placed the building to respond to the public space on the other side of Unter den Linden; the King slid the building to a position that clearly related to his residence. Schinkel further expressed this tension in his design for the building. Rather than simply reinforce the military's allegiance to the monarchy, acted out in its function as the royal guard, Schinkel juxtaposed this function to the new relationship between the military and the general public by making his building out of two very different parts: he surrounded a guard house, designed as a Roman castrum or fortress, with Greek porticos at the front and the back. ${ }^{4}$ In his description of the building, he clearly separated the two elements. He began by talking about the "building itself":

The plan of this entirely freestanding building is more or less modeled on a Roman castrum. Whence the four massive corner towers and the interior court.

Only after finishing his description of the castrum does he describe the portico as

attached or brought on to the front [Der vorne angebrachte Porticus], resting on 10 free columns and the connecting pilasters ${ }^{5}$

The portico signified the public realm in Schinkel's urban works and allowed the Neue Wache to enter into a dialogue with the two most recent public institutions: Knobelsdorff's 1741 Staatsoper, across the street, and Langhans' Brandenburg gate to the west, where Unter den Linden entered the city, built between 1788 and $1791 .^{6}$ Soon after, the Schauspielhaus (1817) and the Altes Museum (1823-4) entered into the conversation. Schinkel's decision to place the Greek portico entry in front of the Roman castrum allowed him to exploit a simple architectural difference between exterior and interior, between Greek and Roman languages, and, in Alberti's terms, between ornament and structure.

Schinkel's Neue Wache was thus the catalyst for a new urban scheme that was to supersede the existing Berlin. But the resonance of the new scheme lay in making clear its conquest of the old city and thus the old order. The construction of an entirely new guard house would not have expressed this notion of conquest as well as the transformation of an old one. The old guard house - the Alte Wache was located slightly to the east of the Neue Wache site, in the shadows of the armory building. Since 1800 , there were plans to replace the old "unsightly" military guard house [die unansehnliche Kanonierwache] with a new, Royal Guard House. . On the far side of the Alte Wache - the future site of the Neue Wache - lay the Grüne Graben [the Green Moat] a part of the old fortifications from the mid-seventeenth 
century . The fortifications did not merely defend the Prussian monarchy against a military enemy; they had been dismantled because they had obstructed the expansion of the suburbs, which were more-or less civilian territory in Berlin. ${ }^{8}$ In his site plan for the new guard house, Schinkel defied the historic predominance of the Royal defense line as he covered over the moat. His Neue Wache stood as the slightly, but significantly, displaced Alte Wache, the castrum representing the unadorned form of the old guard house, renovated with the new public garb. The renovation represented what Schinkel hoped would be the transformation from Hohenzollern to civic Berlin and the birth of a new Prussian identity. The concept of renovation became the means to construct German memory as tension between the present and the past and thus became an appropriate template for the subsequent projects on the site.

How could the same building be used to serve the memory of the Weimar Republic, the Third Reich, the early East Germany, the East Germany steeped in the Cold War, and a reunified Germany? Was an eternal respect for Schinkel and a wish to use his traces to preserve his presence in Berlin the sole basis for repeatedly using the shell of his guard building for a national memorial? As each new period of German history made the Neue Wache ideologically obsolete and demanded its renovation, there were many proposals for using the building as something other than a memorial, as well as for other locations for a national memorial. Each time, however, the Neue Wache and plans for a new memorial converged. Its location, its architectural value, and the fact that the building was one of the few that focused on the historic relationship between the military, the people, and the government, contributed to the Neue Wache's desirabil-

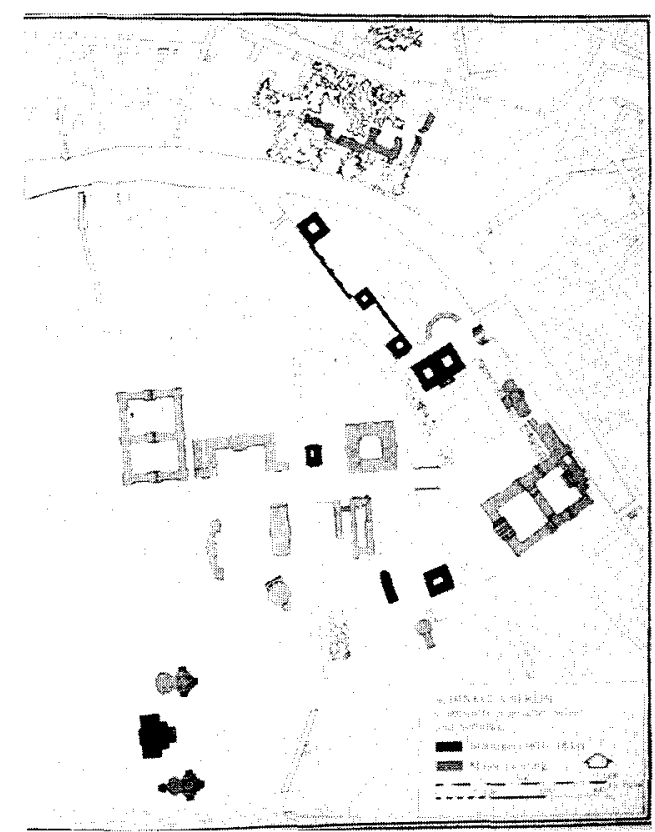

Fig. 2. Plan of Schinkel's Berlin, 1841 with the Neue Wache at the center. From Hermann Pundt, Schinkel's Berlin: A Study in Environmental Planning (Cambridge, Mass.: Harvard University Press, 1972), Plate 73. ity as a national memorial. That the renovation process, which focused on the interior, was not cumulative, but one in which a new project replaced its predecessor, explains how these very different states made use of a similar container to express their different attitudes toward the past.

Schinkel's building was first renovated in the Weimar Period, when it had become functionally as well as ideologically obsolete. The fall of the monarchy eliminated the need for a Royal Guard; the loss of the war made the celebration of victory on the building's exterior inappropriate. Heinrich Tessenow's winning entry in the 1930 competition to renovate the building as a "Memorial Site for those killed in World War I" [Gedächnisstätte für die Gefallenen des Weltkrieges] replaced the work spaces of the living guard with a space for the dead, carefully echoing what had existed there previously. Although the new interior was a single cubic space, Tessenow metaphorically retained the essential feature of the guard's quarters: the separation of the guard from the urban life outside. The interior was completely sealed off from all sources of natural light except for a skylight, which echoed the presence of the old service courtyard. The side windows were filled with brick, laid in the same manner as was the rest of the original wall, literally making a seamless connection between new and old construction. Access to the building was reduced to three doorways sealed by iron gates, displaced artifacts of the fence that had previously surrounded the building outside to protect the guardhouse during the 1848 revolution. Tessenow's original intention further separated the guard from the public: he wanted to allow only visual access to the building except on special - state sanctioned - occasions.

The memorial objects consisted of a granite cube, two candelabra, a bronze tablet inscribed with the dates of the First World War, and a series of wreaths: natural wreaths hung on the side walls and a silver wreath gilded in gold and platinum lay atop the granite cube, which Tessenow described as a sarcophagus. It was as if Tessenow had reached to the Winged Victories on the entablature of Schinkel's

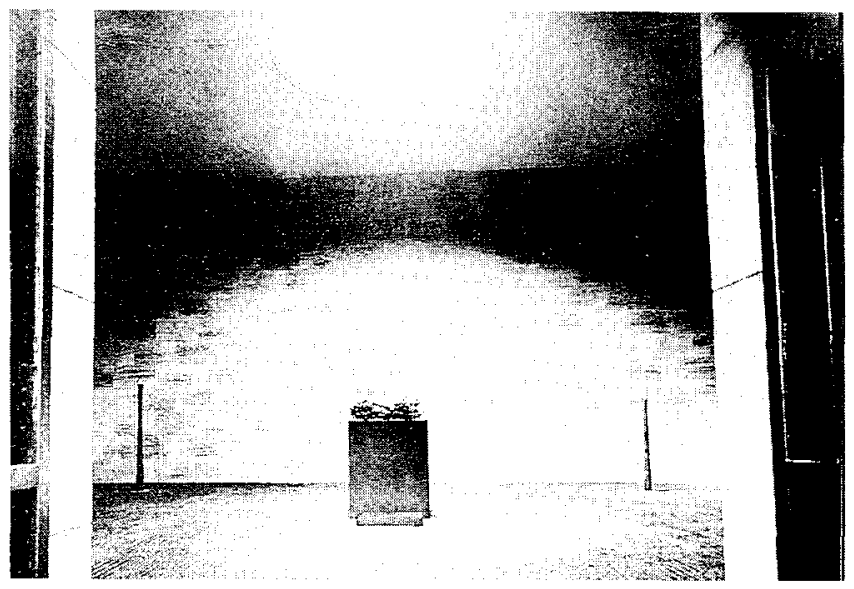

Fig. 3. Interior of the 1931 renovation by Heinrich Tessenow. From "Schwierigkeit zu trauern. Gespräch zurZukunft der Neuen Wache," Streit um die Neue Wache. Zur Gestaltung einer zentralen Gedenkstätte (Berlin: Akademie der Künste, 1993), p.67. 


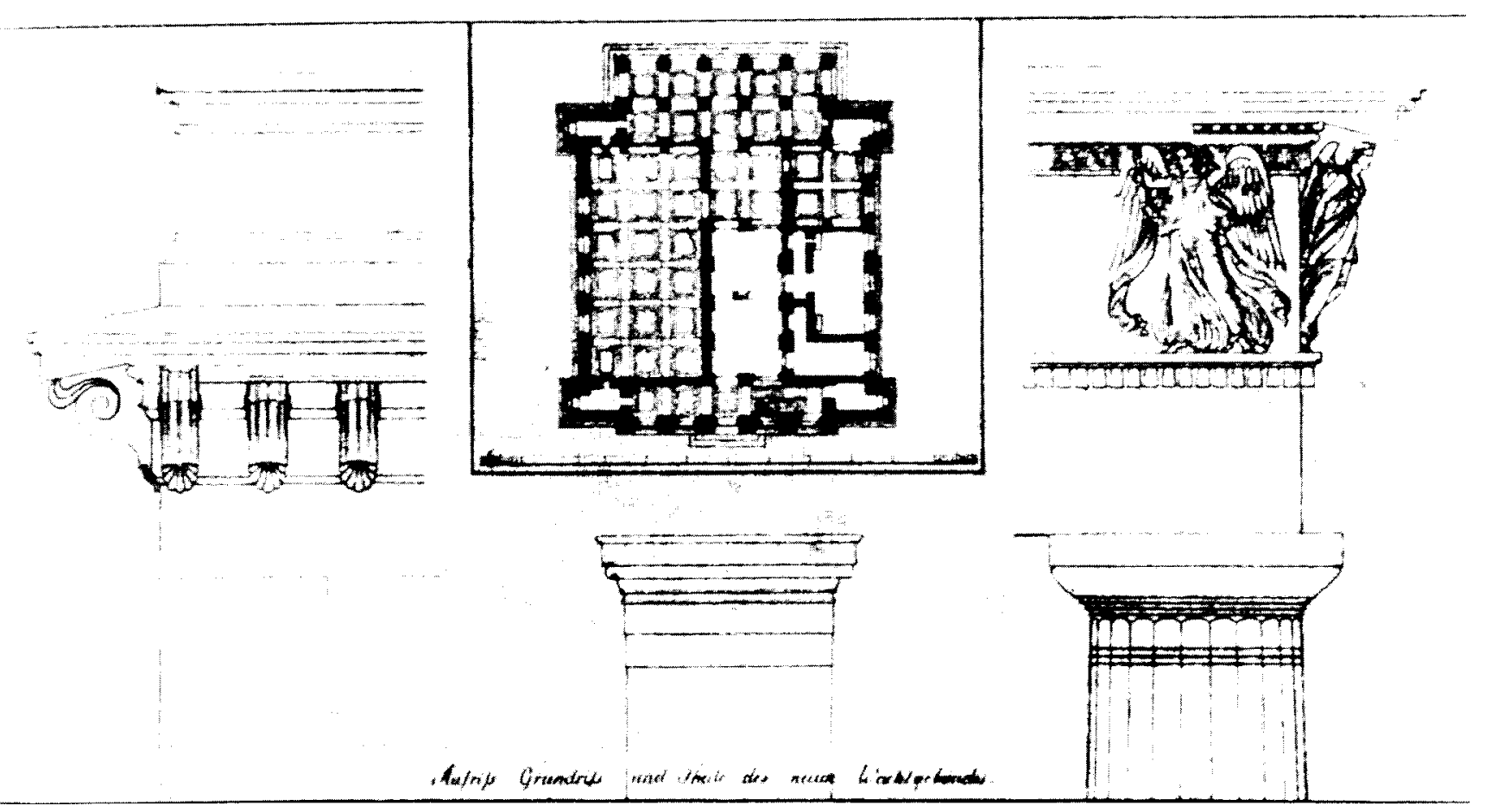

Fig. 4. Plan and details of the Neue Wache by Schinkel. From Schinkel, Collection of Architectural Drawings, Plate 4.

building and taken a wreath to place inside. But the wreath was not the laurel wreath of victory, it was the oak wreath of death.

Tessenow intended to leave the victorious 19 th century origins intact for the Weimar identity by isolating death as a separate affair. Only the laurel wreath of victory would be a part of the public landscape; the oak wreath of death would remain in the precinct of state-controlled ritual.

Tessenow's proposal seemed to reiterate the tensions between the public and the state present in Schinkel's construction of German identity. The monarchy had died, but a state removed from the public still occupied the interior space as it had done for the past century. Both inside and out, however, every trace of the military had disappeared but one: Tessenow had placed an iron cross - the symbol of heroism - in the central portal, between the zone of the public and that of the state. The absence of the military, except in the form of the iron cross, suggested the death of an important component of 19th Century German society during World War I. The portrayal of the consequent social shift as a loss was the subject of Tessenow's memorial project.

The public, however, did not allow the Neue Wache to remain a site to mourn a lost identity. Out of the First World War, the Weimar Republic had emerged and given the public their own voice; with this they had refused a continuity with the past in order to remake their present. In this context, Tessenow's scheme for the memorial was an anachronism. It was a document created from a perspective that no longer existed and was thus a piece of history providing knowledge, but not identity, for the Weimar public. Consequently, the scheme was changed: the public metaphorically broke through the iron gates, cast the iron cross to the side, and claimed the

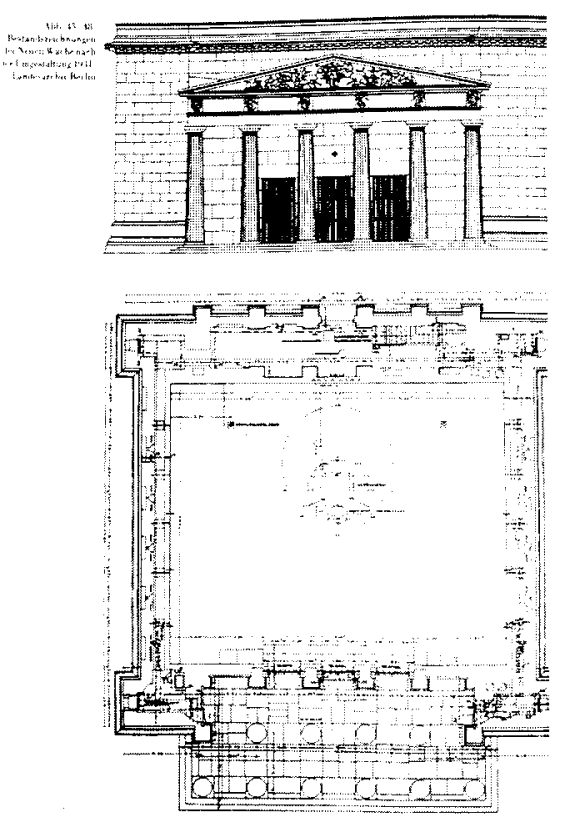

Fig. 5. Elevation and Plan of the Tessenow renovation. From Jürgen Tietz, "Schinkels Neue Wache Unter den Linden," Die Neue Wache Unter den Linden, ed. Christoph Stölzl (Berlin: Koehler and Amelang, 1993), p.48.

interior of the building and, thus, the memory of the war as their own. ${ }^{9}$ They no longer needed to be represented by the military in national consciousness; they were present in their own right. As the barrier between the public and the state dropped away in Tessenow's final scheme, the stone floor turned to paving, reminiscent of Berlin's streets. ${ }^{10}$ The interior of the Neue Wache became a part of the public 
landscape and part of a living German memory.

The emphasis now was on the specific origin of the Weimar Republic, which confronted, rather than absorbed, the 19th Century origins of the modern German state. Remembering in this version of Tessenow's project directly told Weimar Germans who they were and out of what they came, it did not simply inform them about who they had been, but were no longer.

The Nazis only altered the building superficially, uniting the exterior and interior with funerary ornament and a military guard that turned the whole building into a heroic monument. During the Berlin bombings in World War II, the building was severely damaged. After a long debate over the building's future, the East Germans stabilized and restored it in 1957, leaving the war torn Tessenow sarcophagus in place for public view. In 1968, on their twentieth anniversary and at the height of the Cold War, they completely renovated the building, removing the objects of Tessenow's renovation but maintaining its structure. Inside a newly finished space, they placed an eternal flame and tombs of the unknown soldier and the unknown resistance fighter, which they dedicated, as they did in 1957, "to the victims of fascism and militarism.".

Given the sharp ideological turn that followed reunification, the Neue Wache was again obsolete after 1990. Its most recent renovation was completed in 1993, when it was dedicated "to the victims of war and oppression." The project is an interesting combination of ideology and history created by Chancellor Helmuth Kohl and the director of the German History Museum, Christoph Stölzl. They erased all of the traces of the East German projects and almost completely restored Tessenow's design, except for the granite cube and the wreath. This they replaced with a copy of Käthe Kollwitz's "Pietà" of 1937/8.

Although it was actually created during the Nazi period, the "Pieta" was really a product of the post World War I era. Kollwitz made the expressionist sculpture to represent her mourning for her son, who was killed in the war. While contemporary to Tessenow's original design, the sculpture clearly had no place there. The power of Tessenow's design, according to Siegfried Kracauer in 1931, lay in the absence of representing figures. He said:

[The viewer] notices, thanks to the nature [of the details] that essential human qualities are represented in the space. They fill it more than figures would."

Memory in Tessenow's scheme was generated by the interaction of the public with the architecture. Now, the personal memory that was once liberated by Tessenow's architecture is absent, having been cast by the state into a bronze mould. The individual is only present in the documents of history. ${ }^{12}$

The 1993 project poses as the integration of history and memory; it claims to have restored history in order to demonstrate the continuity of German memory. Because of the installation of the Pietà, however, it has in fact reconfigured Weimar history for use by a new German memory. That the

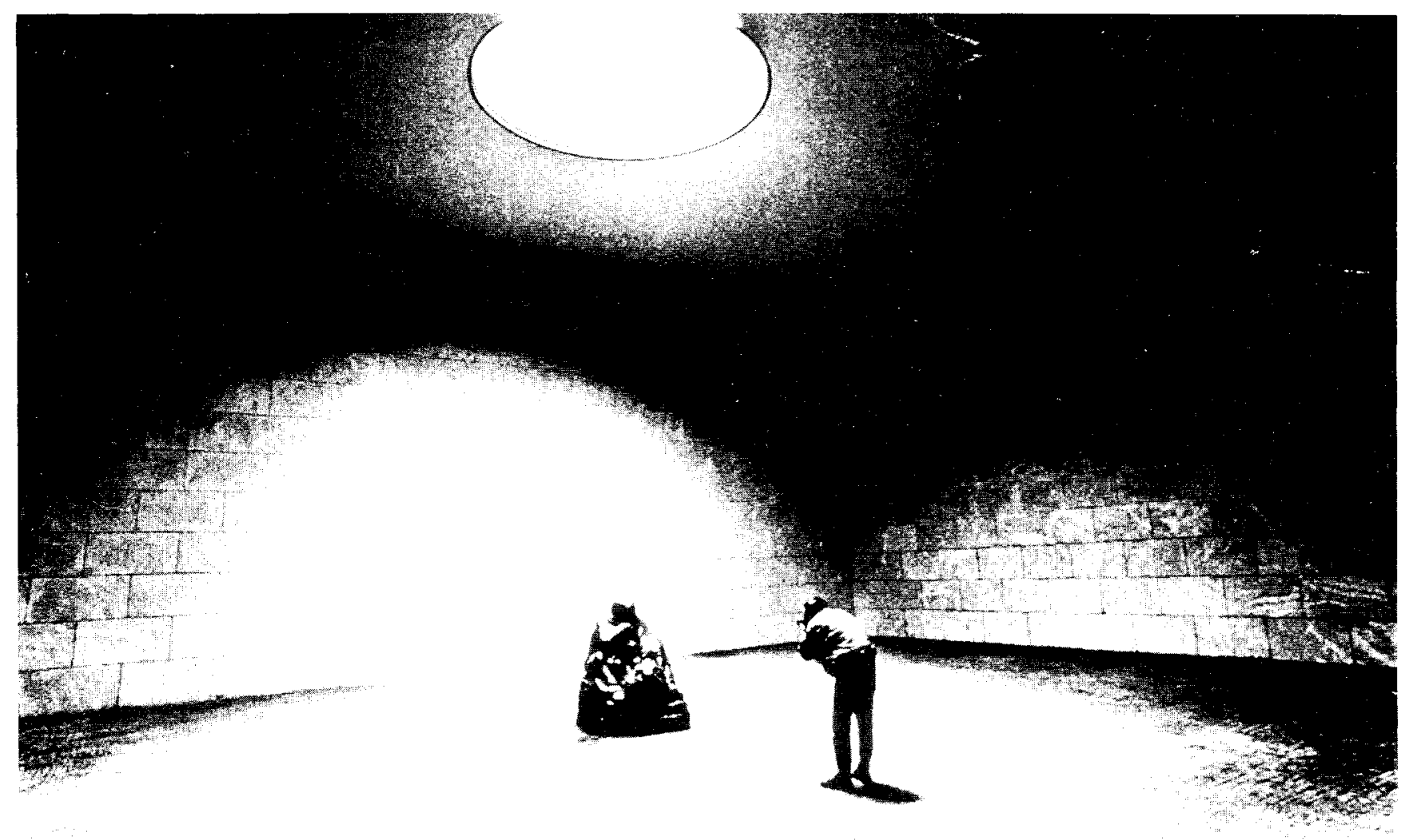

Fig. 6. Interior of the 1993 renovation. From Der Spiegel, no.46 (Nov. 15, 1993):268. 
Pietà is five times the size of the original is a sign of this reconfiguration; it shows that continuity between the memory of the Weimar period and the present can only be created by forcing a history transformed by imagination - by memory into place.

History has not been eliminated, however, but presents the unavoidable challenge to memory that completes the memorial. The site of the struggle of history and memory against their forced identity is at the juncture of interior and exterior: the locus of the military and of ambiguity for both Schinkel and Tessenow. Here hang two bronze plates, descriptions of the history of the building and of the victims of Nazi terror. They hang outside the "contemporary" site of memory; outside the Weimar reconfiguration. The 1993 project attempts to restore German memory to its pre-Nazi era state. But the facts of history, both those that record the oppression of the Nazi period and those that record the changes to the Neue Wache, frame the recreated Weimar juxtaposition of the recent and distant past. At the threshold, it is history that challenges the contemporary use of the Weimar memory. Engraved on bronze tablets, these records strangely echo Tessenow's bronze tablets engraved with the dates of the First World War. Despite memory's attempt to resist history, it is dependent on this documentation - on history - for its existence.

It is the juxtaposition of interior and exterior established by Schinkel, that well anticipated the needs of German memory. It has allowed the German memory builders to - willingly or not - escape a search for unity and integrate the tensions between past and present, between history and memory, into the architectural landscape. The fact that the German memorial has always taken the form of a renovation - or change - is itself an appropriate metaphor for the history of the German National memory, a metaphor of which the name Neue Wache - the new guard house - has always been a trace.

\section{NOTES}

1 Jacques LeGoff, History and Memory, trans. by Steven Randall and Elizabeth Claman, (New York: Columbia, 1992), p.xi.

${ }^{2}$ Ibid., p.54

3 Ibid., p.86

${ }^{4}$ See Eric Forssman's description of the building which reinforces the theory that it is a hybrid: "Dem romischen Vorbild widerspricht allerdings die Offnung durch einen griechischdorischen Portikus." Eric Forssman, Karl Friedrich Schinkel Bauwerke und Baugedanken (Munich: Schnell und Steiner, 1981), p.94.

${ }^{5}$ Karl Friedrich Schinkel, Sammlung Architektonischer Entwürfe , translated as Collection of Architectural Drawings. (original: Berlin: Ernst und Korn, 1866) (reprint: New York: Princeton University Press, 1989), p.1 of the German text.

${ }^{6}$ Eric Forssman talks about the relationships between the porticoes - and thus the buildings - in more specific terms. After pointing out the Doric connection between the NW and the Brandenburg gate, he discusses the NW's relationship to the opera diagonally opposite: to the opera's Corinthian, the NW Doric sets "a more serious counterpart, very different in character." Forssman, p.94.

7 Ibid., p.92.
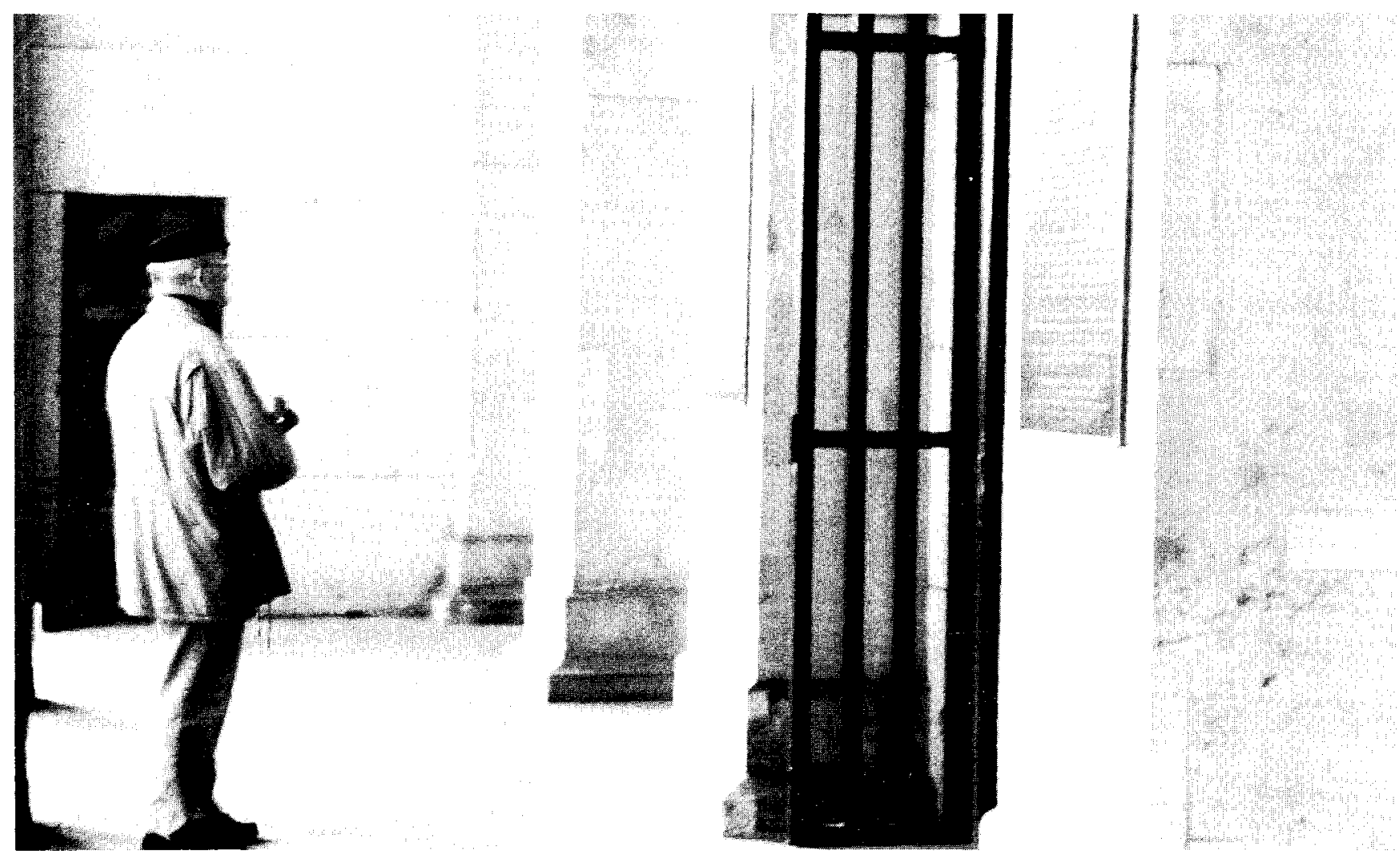

Fig. 7. Brass Plates at the entry to the 1993 memorial. Photo: Francesca Rogier. 
8 The walls were dismantled around 1700 , certainly by 1713 , when Friedrich I built the walls to contain potential military deserters. Hermann Pundt, Schinkel's Berlin: A Study in Environmental Planning (Cambridge, Mass.: Harvard University Press, 1972), p.10-11.

${ }^{9}$ In the published research on the subject, there is no explanation for the literal cause of this change, only a footnote citing material in the Federal Archive in Koblenz. See Jürgen Tietz, "Schinkels Neue Wache Unter den Linden," Die Neue Wache Unter den Linden, ed. Christoph Stölzl
(Berlin: Koehler and Amelang, 1993), p.58, fn.94.

10 A description of the change in design from stone to a mosaic, similar to Berlin's streets is found in Tietz, p.52.

1 Siegfried Kracauer, "Zur Einweihung des Berliner Ehrenmals," Frankfurter Zeitung (June 2, 1931, evening): 1.

12 See Streit um die Neue Wache. Zur Gestaltung einer zentralen Gedenkstätte (Berlin: Akademie der Künste, 1993) and Die Neue Wache Unter Den Linden. Ein Deutsches Denkmal im Wandel der Geschichte, ed. Christoph Stölzl (Berlin: Koehler and Amelang, 1993). 